\title{
Effects of Drying Methods on the Chemical Composition of the Sea Cucumber Holothuria forskali
}

\author{
Khaoula Telahigue ${ }^{1, *}$, Tarek Hajji ${ }^{1,2},{\text { Rabeh } \operatorname{Imen}^{1}, \text { Ouertani Sahbi }}^{3}$ and M'hamed El Cafsi ${ }^{1}$ \\ ${ }^{1}$ University of Tunis El Manar, Faculty of Sciences of Tunis, Research Unit of Physiology and Aquatic Environment, \\ 2092 Tunis, Tunisia \\ ${ }^{2}$ University of Manouba, High Institute of Biotechnology of Sidi Thabet, 2020 Ariana, Tunisia \\ ${ }^{3}$ University of Tunis El Manar, Faculty of Sciences of Tunis, Laboratory for Energy and Heat and Mass Transfer, 2092 \\ Tunis, Tunisia
}

\begin{abstract}
The effects of artisanal and controlled oven drying methods on the biochemical composition of the body wall of the sea cucumber, Holothuria forskali were investigated. Five combinations of temperature $\left({ }^{\circ} \mathrm{C}\right)$ and relative humidity (\%) levels were tested $\left(50^{\circ} \mathrm{C}, 20 \%, 60^{\circ} \mathrm{C}, 25 \% ; 60^{\circ} \mathrm{C}, 15 \%, 60^{\circ} \mathrm{C}, 20 \%\right.$ and $\left.70^{\circ} \mathrm{C}, 20 \%\right)$. The results demonstrate that the treatment $\left(60^{\circ} \mathrm{C}\right.$ and $\left.20 \%\right)$ yields an improvement of the nutritional quality of the initial product. Improvements were particularly noted in terms of the amount of total proteins and the polyunsaturated fatty acids level in the dry body wall of H. forskali.
\end{abstract}

Keywords: Chemical composition; fatty acid; Holothuria forskali; oven drying; solar drying; Tunisia.

\section{INTRODUCTION}

The sea cucumbers belong to the phylum of Echinodermata. They are commonly known as trepang, bêche-de-mer, or gamat. The sea cucumbers have high nutritional values with a high quality protein and low fat levels $[1,2]$. They are also traditional tonic and widely consumed in East Asian countries [3].

From medicinal perspective, some sea cucumbers species are used in traditional medicine in Asia and in the Middle East to treat wounds, eczema, arthritis and hypertension [4]. Several bioactive compounds of trepan have unique biological and pharmacological activities that were reported in numerous studies. These compounds exhibit antibacterial [5], antifungal [6, 7] and antioxidant [8] properties. Furthermore, previous studies revealed that some of sea cucumber species contain potential anti-tumor and immunostimulatory agents [9-11].

Since sea cucumbers can autolyze after they are taken out of sea water, they are mostly processed into dried, boiled or salted products $[12,13]$.

Traditional techniques, which involve salting, repeated boiling and exposure to solar radiation, are long processes that lead to the loss of many active ingredients [3]. In order to yield better quality of dried sea cucumbers, new drying technologies are used. Hot air drying is the simplest method,

\footnotetext{
*Address correspondence to this author at the University of Tunis El Manar, Faculty of Sciences of Tunis, Research Unit of Physiology and Aquatic Environment, 2092 Tunis, Tunisia; Tel: +21623312023;

Fax: +21671537044; E-mail: k_telahigue@yahoo.fr
}

but it leads to significant changes in quality of the products [13-15]. In this respect, the most determinant drying factors to avoid the deterioration of the final product are temperature, humidity and air velocity. Therefore, these three parameters must be optimized for a better quality of the dried product.

Studies relating to the effects of cooking types on fatty acid composition of sea food have been mainly focusing on fish frying and boiling [16-20]. Little information exists regarding the effect of drying on the fatty acid profile of seafood, including sea cucumbers.

The objective of this study is to examine the effects of artisanal and controlled drying methods on the biochemical composition and fatty acids profile of the body wall of Holothuria forskali that are collected in Tunisian coasts.

\section{MATERIAL AND METHODOLOGY}

\subsection{Materials}

Two hundred and ten (210) live specimens of sea cucumbers Holothuria forskali (average body weight 100g) were hand-picked by scuba diving (Fig. 1 below shows the harvesting sites of sea cucumbers). They were collected from the Northern East cost of Tunisia in the locality of Bizerte.

\subsection{Pretreatment}

The sea cucumbers were transported to laboratory in seawater. The body of each specimen was cut from the anus nearly to the oral organ, and then their viscera were 
removed. The body walls were washed carefully with distilled water.

\subsection{Drying Trials}

\subsubsection{Solar Drying}

After a 45 minutes boiling time in sea water, the body walls of eviscerated sea cucumbers were drained, salted and sun dried for few days until "stone dried" (four to five days).

\subsubsection{Oven Drying}

Controlled drying was undertaken through a convective hot air drying processing system (Fig. 2) [21]. The unit was composed of a centrifugal blower to aspire the ambient air, an electrical resistance for air heating, a heating control unit, a steam air moistening section, the sensors and a drying chamber. A high precision balance was installed at the lower part of the drier. A controlled automated system was used to adjust temperature, air velocity and relative humidity.

The measurement sensors and the data recording and controlling systems are connected to a computer. Hot air was vertically orientated on the samples to ensure optimum conditions for air-product contact.

To assess optimal environment for the sea cucumber drying, five conditions were evaluated. They are detailed in the Table 1.

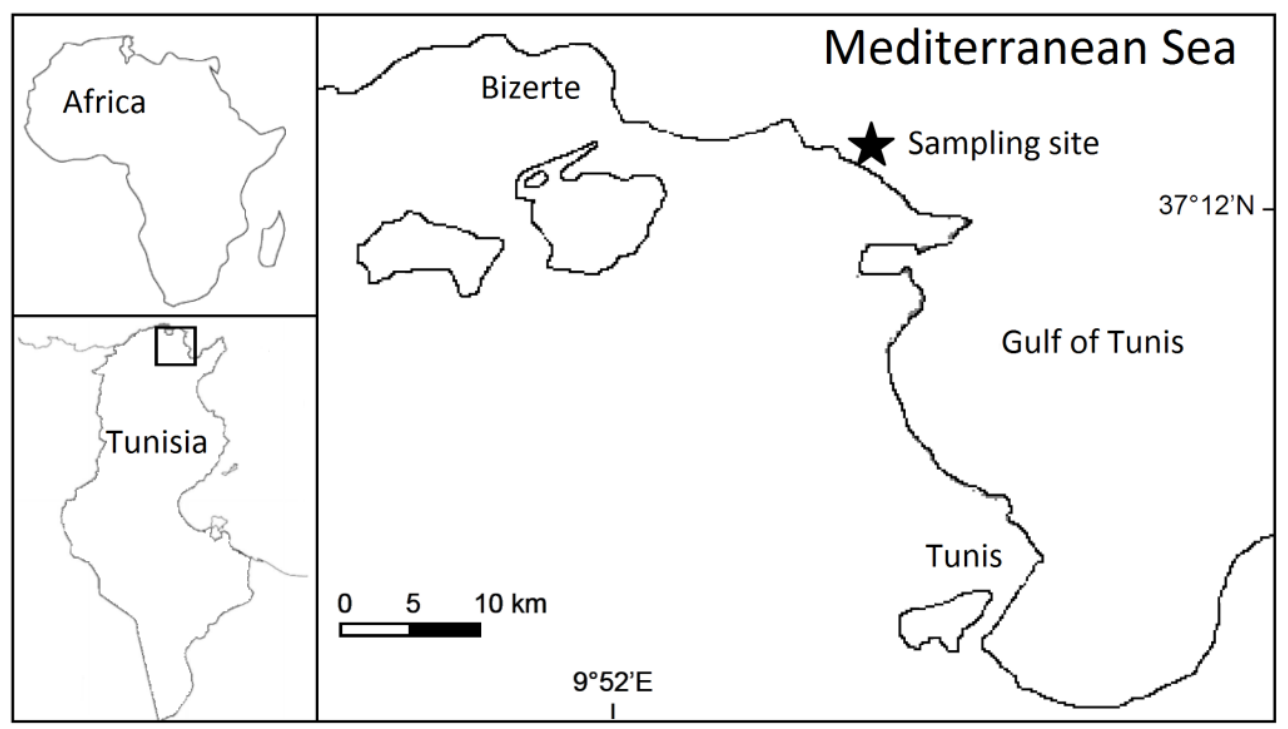

Fig. (1). Sampling site located in the Northern East cost of Tunisia.

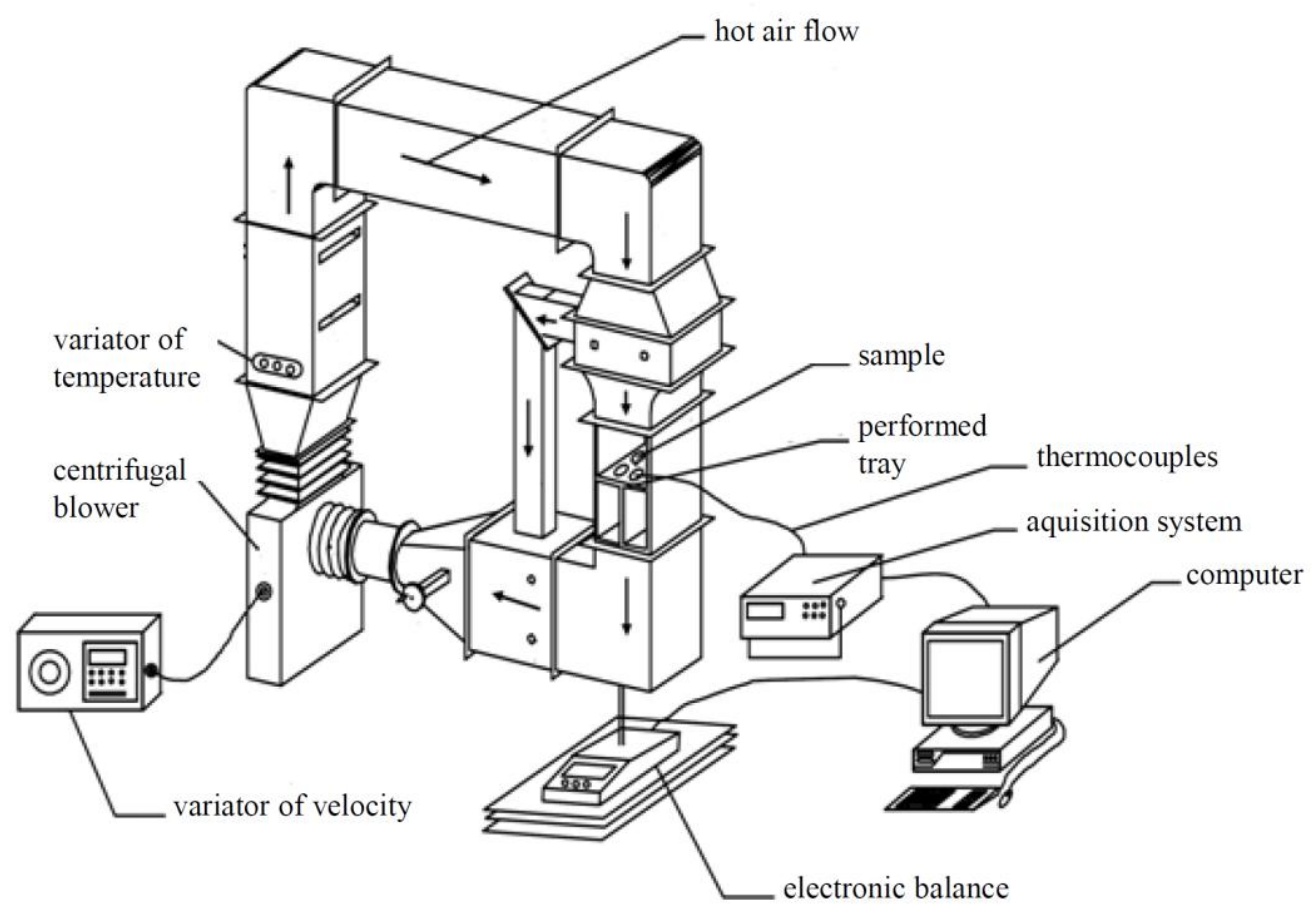

Fig. (2). Dryer system (Hassini et al. [21]). 
Table 1. Experimental Conditions of Drying Processes. Treat: Treatment

\begin{tabular}{|c|c|c|c|}
\hline Treatment & Temperature $\left({ }^{\circ} \mathbf{C}\right)$ & Relative Humidity (\%) & Air Velocity $(\mathbf{m} / \mathbf{s})$ \\
\hline \hline Treat. 1 & 50 & 20 & 2 \\
\hline Treat. 2 & 60 & 25 & 2 \\
\hline Treat. 3 & 60 & 15 & 2 \\
\hline Treat. 4 & 60 & 20 & 2 \\
\hline Treat. 5 & 70 & 20 & 2 \\
\hline
\end{tabular}

\subsection{Analysis of Sample}

\subsubsection{Moisture Content}

Moisture content wet basis [M.C. (w.b.)] was determined by oven drying at $105^{\circ} \mathrm{C}$ for $24 \mathrm{~h}$ using the following formula according to Ranganna [22]:

$\operatorname{MC}(w . b)=.\frac{w_{1}-w_{2}}{w_{1}} * 100$

Where,

$\mathrm{w}_{1}$ : weight of sample before drying and $\mathrm{w}_{2}$ : weight of dried sample.

\subsubsection{Protein Estimation}

Protein concentration was determined as described by Lowry et al. [23] with bovine serum albumin (BSA) as standard.

\subsubsection{Total lipid Extraction}

Lipids were extracted according to the Folch method [24] with the chloroform-methanol solvent mixture $(2: 1, \mathrm{v} / \mathrm{v})$ containing $0.01 \%$ butylated hydroxytoluene (BHT) as the antioxidant.

\subsubsection{Fatty acid Analysis}

After evaporation to dryness, lipid extracts were transesterified according to the method of Cecchi [25]. Separation of FAMEs was carried out on a HP 6890 gas chromatograph with a split/splitless injector equipped with a flame ionization detector at $275^{\circ} \mathrm{C}$, and a $30 \mathrm{~m}$ HP Innowax capillary column with an internal diameter of $250 \mathrm{~lm}$ and a $0.25 \mathrm{~lm}$ film thickness. Injector temperature was held at $250^{\circ} \mathrm{C}$. The oven was programmed to rise from 50 to $180^{\circ} \mathrm{C}$ at a rate of $4 \mathrm{C} / \mathrm{min}$, from 180 to $220^{\circ} \mathrm{C}$ at $1.33 \mathrm{C} / \mathrm{min}$ and to stabilize at $220^{\circ} \mathrm{C}$ for 7 minutes. The carrier gas was nitrogen.

Identification of FAMEs was based on the comparison of their retention times with those of a mixture of methyl esters (SUPELCO PUFA-3). Fatty acid peaks were integrated and analyzed using the HP chemstation software.

All chemical analyses were performed in triplicate. The results were expressed in dry terms (g/100g dry weight) for protein and fat. Fatty acid contents were expressed as percentages of total fatty acids. Data were presented by calculating the mean value \pm standard deviation.

\subsection{Statistical Analysis}

Data was analyzed using the software " $R$ ". Values are presented as mean \pm SD. To assess significant differences between means, the one way Analysis of Variance (ANOVA) followed by the Duncan test was applied. Differences were considered significant when $\mathrm{P}<0.05$.

\section{RESULTS}

Fig. (3) relates the moisture content of sea cucumber body wall to drying time for different oven treatments. The curve of best fit for the drying process was recorded for the

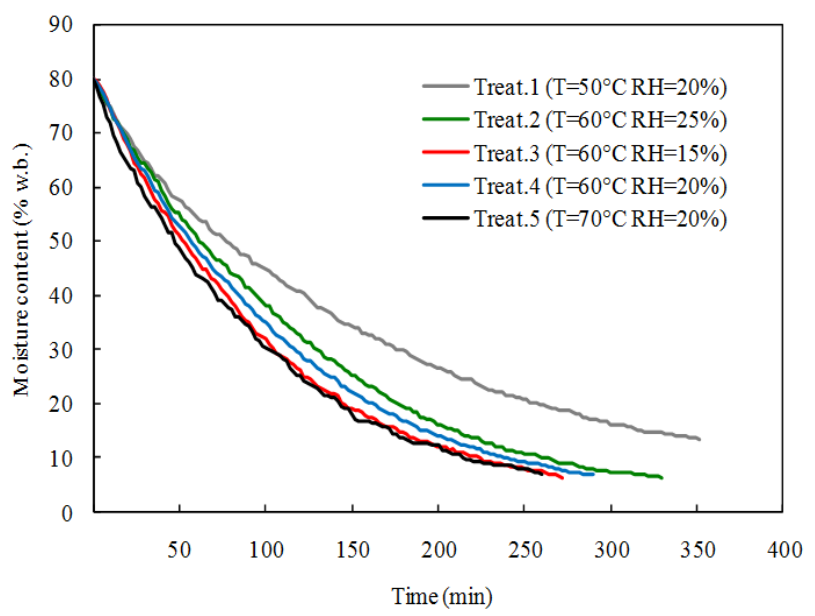

Fig. (3). Variations of the moisture content of the sea cucumber body wall vs. drying time obtained at different drying treatments. 
body wall that was exposed to a $70^{\circ} \mathrm{C}$ temperature and a 20 $\%$ relative humidity (Treat.5). This condition allows to gain 12 minutes of drying time in comparison with Treat.3, 30 minutes with the Treat.4, 70 and 100 minutes with the Treat. 2 and Treat.1, respectively.

The effect of different drying treatments on protein content in the body wall of $H$. forskali is given in the Fig. (4). Compared to the raw samples, results show that the oven treatments and sun-drying significantly increase protein content $(p<0.05)$. The highest protein content was reported in the sea cucumber processed with the Treat. 5 that reached $52.4 \%$ of the dry weight.

As reported in Fig. (5), the raw body wall of $H$. forskali appeared to be relatively low in fat $(0.40 \%)$. This value was insignificantly decreased $(p>0.05)$ by the sun-drying $(0.34 \%)$. However, we noted that different oven treatments induced a significant raise of fat content $(p<0.05)$. The highest increases $(0.66 \%, \quad 0.67 \%$ and $0.63 \%)$ are respectively recorded for three conditions under a relative humidity of $20 \%$ coupled with a $50^{\circ} \mathrm{C}, 60^{\circ} \mathrm{C}$ and $70^{\circ} \mathrm{C}$ temperature levels.

The fatty acids compositions of the raw and dried body wall of $H$. forskali are given in Table 2 . Fatty acids present in the raw body wall at $5 \%$ or more of the total fatty acids were: C14:0, C16:0, C18:0, C18:1n-7, C18:1n-9, C22:1 and C16:3.

Different drying treatments (sun and oven) induced a significant increase $(p<0.05)$ of the sum of saturated fatty acids ( $\sum$ SFA). We noted that the fifth oven drying treatment (Treat.5: $\left.70^{\circ} \mathrm{C}, 20 \%\right)$ exhibits the highest value $(76.9 \%)$. These results were the consequence of the strong increase of the C16:0 and the C18:0 that were recorded at different drying processes. The sum of monounsaturated fatty acids ( $\sum$ MUFA), shows a decline $(p<0.05)$ in the solar-dried and the oven dried body walls.

The sum of polyunsaturated fatty acids ( $\sum$ PUFA) shows different tends along the drying processes. Dried samples

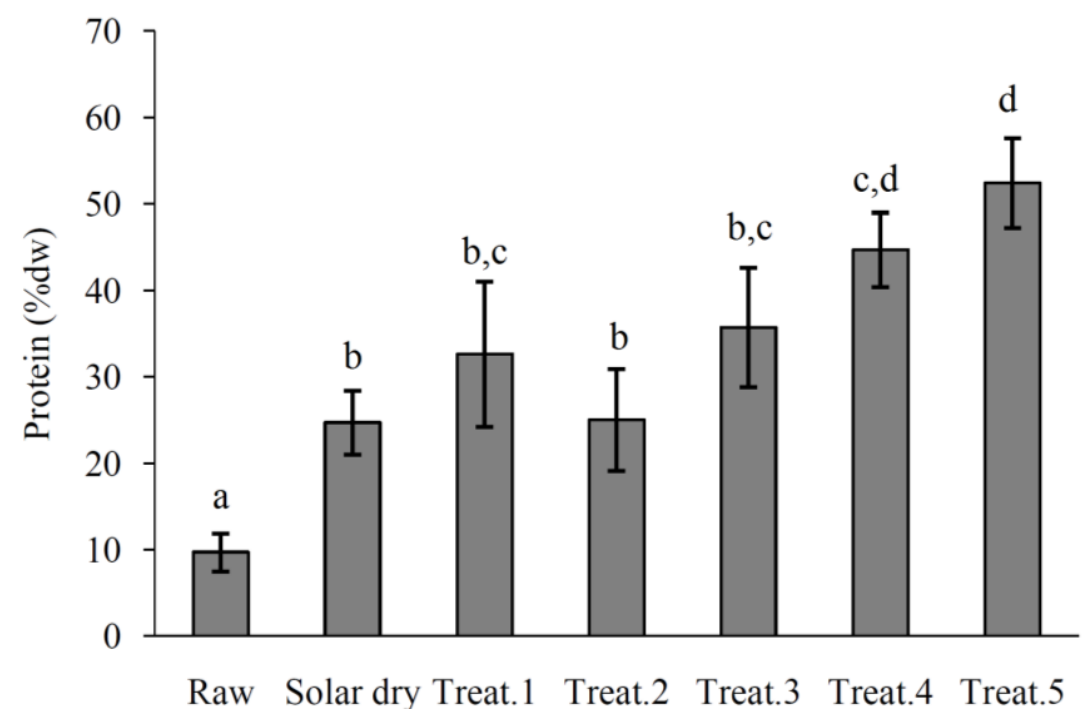

Fig. (4). Total protein content $(\mathrm{g} / 100 \mathrm{~g})$ in the raw and dried body wall of the sea cucumber Holothuria forskali. Different letters indicate significantly different values (Duncan's $\mathrm{p}<0.05$ ) between treatments.

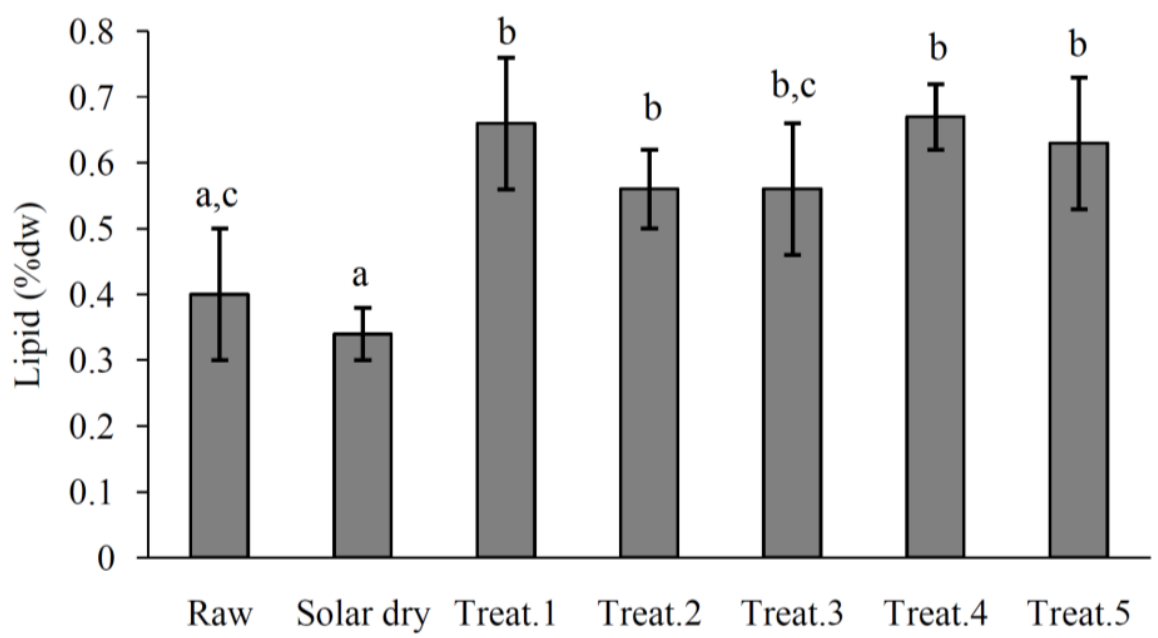

Fig. (5). Total lipid content $(\mathrm{g} / 100 \mathrm{~g})$ in the raw and the dried body wall of the sea cucumber Holothuria forskali. Different letters indicate significantly different values (Duncan's $\mathrm{p}<0.05$ ) between treatments. 
with Treat. 1 and Treat.5 were significantly $(p<0.05)$ lower in total polyunsaturated fatty acids $(16.1 \%$ and $17.3 \%$, respectively) than the raw sample (23.7\%). However, the $\sum$ PUFA was not significantly affected $(p>0.05)$ by the sun drying (19.5\%) and by the oven drying for Treat.3 (27.6\%), Treat.2 (21.3\%) and Treat.4 (23.7\%).

Among the PUFAs group, results show that the n-3 fatty acid content (as \% of total fatty acids) in raw bêche-de-mer was $4.1 \%$. Different drying methods led to significant increase in total $\mathrm{n}-3$ PUFA $(p<0.05)$. The highest value $(13.8 \%)$ was recorded for Treat.2. This treatment shows also the highest docosahexaenoic acid (C22:6n-3, DHA) and eicosapentaenoic acid (C20:5n-3, EPA) contents (2.3\% and $6.2 \%$, respectively) when compared with the other samples.

Concerning the (n-6) PUFAs, results show that the dihomo-gamma-linolenic acid (C20:3n-6) was the major component of this series in different analyzed samples except for those dried with Treat.3. These revealed an interesting elevation $(p<0.05)$ of the arachidonic acid (ARA, C20:4n-6) which reached $4.8 \%$.

When calculating the ratio of omega- 3 to omega- 6 fatty acids, we noted that different drying methods led to a significant increase of this ratio. Values range from 0.6 in the raw body wall to 3.0 and 5.8 for Treat. 2 and Treat.5.

Table 2. Fatty Acid Composition of Total Lipids Extracted from the Body Wall of the sea Cucumber Holothuria forskali (n=6)

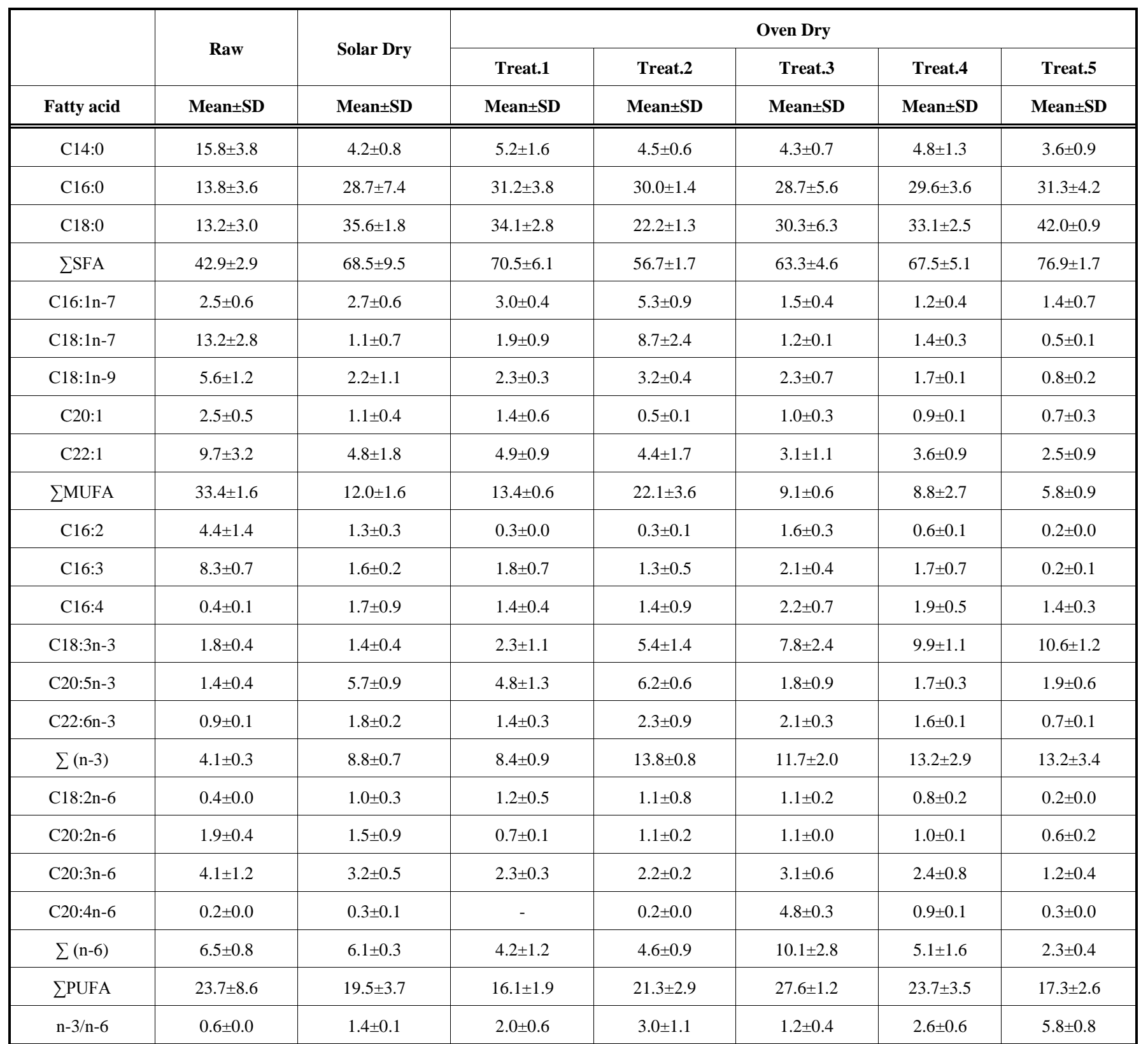

Data are expressed as mean percentages of total fatty acids. SAFA: sum of saturated fatty acids, MUFA: sum of monounsaturated fatty acids, PUFA: sum of polyunsaturated fatty acids, Treat: treatment. 


\section{DISCUSSION}

Biochemical analysis of the raw and the dried body wall of $H$. forskali revealed that proteins are the major compounds. However, fat content is rare. We note that the protein content constitutes $9.7 \%$ of the fresh $H$. forskali body wall while total fats do not exceed $0.4 \%$. These findings are in agreement with those obtained for other fresh sea cucumber species such as $H$. scabra [26], $H$. tubulosa, $H$. Polii and H. mammata [27]. The different drying treatments used in this study induced a significant increase in the protein content of the $H$. forskali trepan. In this study, the highest amount of protein for the processed sea cucumber reached $52.4 \%$. It was obtained under $70^{\circ} \mathrm{C}$ and $20 \%$ oven drying conditions. This result concurs with the range that is reported by Wen et al. [2]. These authors found that the protein content of eight common commercially processed sea cucumber species varied from 40.7 to $63.3 \%$.

The significant increase in the protein content levels has been similarly reported for several dried fish species [28-32]. Such a result seems to be the consequence of dehydration, which tends to concentrate protein as suggested by $\mathrm{Wu}$ and Mao [33] in dried fish filet. Furthermore, Chukwu and Shaba [30] reported that protein nitrogen was not lost during drying. In the contrary, the protein content increased with the reduced moisture level in catfish (Clarias gariepinus).

In this study, the oven dried samples show highest fat content than in raw and sun dried samples. The oven dried process seems to improve the protein quality and prevents lipid oxidation as reported for the grass carp (Ctenopharyngodon idellus) that is dried with the microwave process [33] and the catfish processed with an electric oven [30].

The lower lipid content observed in sundried "bêche-demer" could be associated with the oxidation of fat as demonstrated by Kabahenda et al. [34]. Similar results were recorded by Akinneye et al. [35] in fish Bonga spp, Sardinella spp and Heterotis niloticus. In fact, the lipid of traditional salted sun-dried seafood is highly susceptible to oxidation during processing and storage [36,27]. Literature has reported that sodium chloride acts as a pro-oxidant factor by enhancing the pro-oxidant effect [37].Thus, the salted sun-dried trepangs of $H$. forskali are more prone to oxidation than the oven dried ones because of their higher exposure to light and oxygen [36].

In terms of fatty acids composition, different drying treatments induce a significant increase of the $\sum$ SFA while leading to a strong decline of the $\sum$ MUFA in the body wall. These observations are in discordance with those reported by Aydin et al. [27] for the dried $H$. tubulosa, $H$. polii and $H$. mammata. These authors reported that the drying process results in significant decrease of the $\sum$ SFA against an increase of the $\sum$ MUFA for $H$. tubulosa and $H$. mammata and an elevation of both $\sum$ SFA and $\sum$ MUFA for $H$. polii. Concerning the $\sum$ PUFA, we have recorded that the $\sum$ PUFA significantly decreases in $H$. forskali after the Treat. 1 and treat.5 and remain insignificantly invariable for the rest of the other treatments. Our results support the findings of Aydin et al. [27] who have shown that the effects of the drying process on the SFA, MUFA and PUFA depend on species, drying methods and fatty acid types.

In this study, most of the n-3PUFAs show increasing contents after drying. Same results were recorded in fillets fish processed by hot air and microwave drying [33].

We have noted that, contrary to the raw samples, proportions of the n-3PUFAs in dried body walls of $H$. forskali were higher than those of n-6 PUFA. Consequently, we have recorded an increase of the $\omega-3 / \omega-6$ ratio. The $\omega$ $3 / \omega-6$ ratio is a peculiar indicator of the nutritional value of seafood [38, 39]. It is also considered as an important index of the fatty acid role in human health [40]. According to the same author, the appropriate balance recommended of the $\omega$ $3 / \omega-6$ ratio varies from 1.1 to 1.4 .Our study indicates that the dried body walls of $H$. forskali offer an interesting $\omega-3 / \omega-6$ ratio that exceeds the recommended value to reach 5.8 under the oven Treat.5. Hence, $H$. forskali trepang could be considered as an important food additive that can contribute to an equilibrated polyunsaturated fatty acid intake.

Among the n-3PUFA, the highest mean values of the EPA and the DHA were obtained by the Treat.2. It has been reported that drying processes significantly increase the relative contents of EPA and DHA in fish [33].

Taking into consideration the drying time and the nutritional quality (total proteins and $\sum$ PUFA) of the final product, Treat. $4\left(\mathrm{~T}=60^{\circ} \mathrm{C}, \mathrm{RH}=20 \%\right)$ seems to offer the optimum drying conditions among the tested combinations of temperature and humidity.

$\begin{array}{lll}\text { ABBREVIATION } & \\ \text { BHT }= & \text { Butylated Hydroxytoluene } \\ \text { SFA }= & \text { Saturated Fatty Acids } \\ \text { MUFA }= & \text { Monounsaturated Fatty Acids } \\ \text { PUFA }= & \text { Polyunsaturated Fatty Acids } \\ \text { DHA }= & \text { Docosahexaenoic Acid (C22:6n-3) } \\ \text { EPA }= & \text { EicosapentaenoicAcid (C20:5n-3) } \\ \text { ARA }= & \text { Arachidonic Acid (C20:4n-6) }\end{array}$

\section{CONFLICT OF INTEREST}

The authors confirm that this article content has no conflicts of interest

\section{ACKNOWLEDGEMENTS}

The authors are grateful for the collaboration of the "Laboratory for Energy and Heat and Mass Transfer, Faculty of Sciences of Tunis". Similar thanks go to the anonymous reviewer for improving the final version.

\section{REFERENCES}

[1] Taboada MC, Gonzalez M, Rodriguez E. Value and effects on digestive enzymes and serum lipids of the marine invertebrate Holothuria forskali. Nutr Res 2003; 23: 1661-70.

[2] Wen J, Hu C, Fan S. Chemical composition and nutritional quality of sea cucumbers. J Sci Food Agric 2010; 90: 2469-74. 
[3] Duan X, Zhang M, Mujumdar AS. Study on a combination drying technique of sea cucumber. Drying Technol 2007; 25(12): 2011-9.

[4] Ridzwan BH. Sea Cucumber: The Malaysian Heritage. $1^{\text {st }}$ ed. IIUM press 2007.

[5] Beauregard KA, Truong NT, Zhang H, Lin W, Beck G. The detection and isolation of a novel antimicrobial peptide from the echinoderm, Cucumaria frondosa. Adv Exp Med Biol 2001; 484: $55-62$.

[6] Kumar R, Chaturvedi AK, Shuklab PK, Lakshmia V. Antifungal activity in triterpene glycosides from the sea cucumber Actinopyga lecanora. Bioorg Med Chem Lett 2007; 17: 4387-91.

[7] Ismail H, Lemriss S, Ben Aoun Z, et al. Antifungal activity of aqueous and methanolic extracts from the Mediterranean sea cucumber, Holothuria polii. J Mycol Med 2008; 18: 23-6.

[8] Althunibat OY, Bin Hashim R, Taher M, Daud JM, Ikeda MA, Zali BI. In vitro antioxidant and antiproliferative activities of three Malaysian sea cucumber species. Eur. J. Sci. Res 2009; 37: 376-87.

[9] Tian F, Zhang X, Tong Y, et al. A new sulfated saponin from sea cucumber, exhibits anti-angiogenic and anti-tumor activities in vitro and in vivo. Cancer Biol Ther 2005; 4: 874-82.

[10] Aminin DL, Gorpenchenko TY, Bulgakov VP, Andryjashchenko PV, Avilov SA, Kalinin VI. Triterpene Glycoside Cucumarioside A2-2 from sea cucumber stimulates mouse immune cell adhesion, spreading, and motility. J Med Food 2011; 14 (6): 594-600.

[11] Su X, Xu C, Li Y, Gao X, Lou Y, Ding J. Antitumor activity of polysaccharides and saponin extracted from sea cucumber. J Clin Cell Immunol 2011; 2: 105.

[12] Conand C. The fishery resources of pacific island countries. Part 2: Holothurians, FAO Fisheries Technical Paper 1990. Retrieved from FAO website: http: //www.fao.org/docrep/008/t0293e/t0293e00.$\mathrm{htm}$

[13] Duan X, Zhang M, Mujumdar AS, Wang SJ. Microwave freeze drying of sea cucumber Stichopus japonicus. J Food Eng 2010; 96 : 491-7.

[14] Ratti C. Hot air and freeze-drying of high-value foods: a review. J Food Eng 2001; 49 (4): 311-9.

[15] Mujumdar AS. Guide to industrial drying principles, Equipment and new developments. Colour Publications 2004.

[16] Regulska-Ilow B, Ilow R. Comparison of the effects of microwave cooking and conventional cooking methods on the composition of fatty acids and fat quality indicators in herring. Nahrung/Food 2002; 46: 383-8.

[17] Gladyshev MI, Sushchik NN, Gubanenko GA, Demirchieva SM, Kalachova GS. Effects of way of cooking on content of essential polyunsaturated fatty acids in muscle tissue of humpback salmon (Oncorhynchus gorbuscha). Food Chem 2006; 96: 446-51.

[18] Türkkan A, Cakli S, Kilinc B. Effects of cooking methods on the proximate composition and fatty acid composition of sea bass (Dicentrarchus labrax Linneaeus). Food Bioprod Process 2008; 11: $1-4$.

[19] Weber J, Bochi VC, Riberio CP, Victorlo AM, Emanuelli T. Effect of different cooking methods on the oxidation, proximate and fatty acid composition of silver catfish (Rhamdia quelen) fillets. Food Chem 2008; 106: 140-6.

[20] Mnari-Bhouri A, Jrad-Harzallah H, Dhhibi M, Bouhlel I, Hammami M, Chaouch A. Effects of frying on the fatty acid composition in farmed and wild gilthead sea bream (Sparus aurata). Int J Food Sci Technol 2010; 45: 113-23.

[21] Hassini L, Azzouz S, Belghith A. Estimation of the moisture diffusion coefficient of potato during hot-air drying. Proceedings of the 14th International Drying Symposium; 2004; Sao Paulo, Brazil.

[22] Ranganna S. Handbook of Analysis and Quality Control for Fruit and Vegetable Products. Tata McGraw-Hill 1986.

[23] Lowry OH, Rosebrough NJ, Farr AL, Randall RJ. Protein measurement with the folin phenol reagent. J Biol Chem 1951; 193: $265-75$.

[24] Folch J, Less M, Sloane-Stanley CH. A simple method for the isolation and purification of total lipids from animal tissues. J Biol Chem 1957; 266: 497-509.

[25] Cecchi G, Basini S, Castano C. Méthanolyse rapide des huiles en solvant. Rev Fr Corps Gras 1985; 32: 163-4.

[26] Özer NP, Mol S, Varlık C. Effect of the handling procedures on the chemical composition of sea cucumber. Turk J Fish Aquat Sc 2004; 4: 71-4.

[27] Aydin M, Sevgili H, Tufan B, Emre Y, Köse S. Proximate composition and fatty acid profile of three different fresh and dried commercial sea cucumbers from Turkey. Int J Food Sci Technol 2011; 46: 500-8.

[28] Puwastien P, Judprasong K, Kettwan E, Vasanachitt K, Nakngamanong Y, Bhattacharjee L. Proximate composition of raw and cooked Thai freshwater and marine fish. J Food Comp Anal 1999; 12: 9-16.

[29] Gokoglu N, Yerlikaya P, Cengiz E. Effects of cooking methods on the proximate composition and mineral contents of rainbow trout (Oncorhynchus mykiss). Food Chem 2004; 84: 19-22.

[30] Chukwu O, Shaba IM. Effects of Drying Methods on Proximate Compositions of Catfish (Clarias gariepinus). World J Agric Sci 2009; 5: 114-6.

[31] Ali A, Ahmadou D, Mohamadou BA, Saidou C, Tenin D. Influence of traditional drying and smoked-drying on the quality of three fish species (Tilapia nilotica, Silurus glanis and Arius parkii) from Lagdo Lake, Cameroon. J Anim Vet Adv 2011; 10(3): 301-6.

[32] Immaculate J, Sinduja P, Jamila P. Biochemical and microbial qualities of Sardinella fimbriata sun dried in different methods. Int Food Res J 2012; 19(4): 1699-703.

[33] Wu T, Mao L. Influences of hot air drying and microwave drying on nutritional and odorous properties of grass carp (Ctenopharyngodonidellus) fillets. Food Chem 2008; 110: 647-53.

[34] Kabahenda MK, Omony P, Hüsken SMC. Post-harvest handling of low-value fish products and threats to nutritional quality: a review of practices in the Lake Victoria region. Regional Programme Fisheries and HIV/AIDS in Africa: Investing in Sustainable Solutions. The World Fish Center 2009. Retrieved from http: //www.worldfishcenter.org/resource_centre/WF_3373.pdf

[35] Akinneye JO, Amoo IA,Bakare OO. Effect of drying methods on the chemical composition of three species of fish (Bonga spp., Sardinella spp. and Heterotisniloticus). Afr J Biotechnol 2010; 9 (28): 4369-73.

[36] Smith G, Hole M. Browning of salted sun-dried fish. J Sci Food Agric 1991; 51: 193-205.

[37] Kanner J, Harel S, Jaffe R. Lipid peroxidation of muscle food as affected by NaCl. J Agric Food Chem1991; 39: 1017-21. 
[38] Orban E, Di Lena G, Masci M, Nevigato T, Casini I, Caproni R. Growth, nutritional quality and safety of oysters (Crassostrea gigas) cultured in the lagoon of Venice (Italy). J Sci Food Agric 2004; 84: 1929-38.

[39] Tokur B, Ozkutuk S, Atici E, Ozyurt G, Ozyurt CE. Chemical and sensory quality changes of fish fingers, made from mirror carp
(Cyprinus carpio L., 1758), during frozen storage. Food Chem 2006; 99: 335-41.

[40] Simopoulos AP. The importance of the ratio of omega-6/omega-3 essential fatty acids. Biomed Pharmacother 2002; 56(8): 365-79.

(c) Telahigue et al.; Licensee Bentham Open.

This is an open access article licensed under the terms of the Creative Commons Attribution Non-Commercial License (http://creativecommons.org/licenses/ by-nc/3.0/) which permits unrestricted, non-commercial use, distribution and reproduction in any medium, provided the work is properly cited. 